\title{
Does human milk reduce infection rates in preterm infants? A systematic review
}

\author{
A de Silva, P W Jones, S A Spencer
}

Arch Dis Child Fetal Neonatal Ed 2004;89:F509-F513. doi: 10.1136/adc.2003.045682

See end of article for authors' affiliations

......................

Correspondence to:

Dr S A Spencer, Neonatal Unit, University Hospital of North, Staffordshire, Newcastle Road, Stoke-onTrent ST4 6QG, UK; andy. spencer@uhns.nhs.uk

Accepted 15 May 2004
One of the reasons for advocating human milk (HM) feeding for preterm infants is the belief that this provides the infant with a degree of protection from infection. Providing fresh HM for such infants is challenging for mothers and staff, and consequently it is important that its benefits are rigorously evaluated. Therefore a systematic review was undertaken to assess all publications concerned with human milk feeding and infection in very low birth weight (VLBW) preterm infants. Nine studies - six cohort and three randomised controlled trials (RCT)-were assessed using predefined criteria. Methodological problems included poor study design, inadequate sample size, failure to adjust for confounding variables, and inadequate definitions of HM feeding and outcome measures. In conclusion, the advantage of HM in preventing infection in preterm, (VLBW) infants is not proven by the existing studies. Recommendations are made regarding the methodology required for further study of this important topic.
A mong the reasons used to advocate feeding preterm low birth weight infants human milk (HM) is the belief that HM is advantageous in reducing infections when compared to preterm formula. Protective effects of breast feeding in reducing sepsis and diarrhoea in term infants and children have been reported in developing countries. $^{1-3}$ Furthermore, breast milk has anti-infective properties due to the high content of IgA, lysozyme, lactoferrin, and interleukins. ${ }^{45}$ Non- pathogenic maternal bacteria transmitted via breast milk and skin to skin contact may promote enteromammary immune responses. ${ }^{6}$ Biochemical and microbiological studies suggest that these properties apply to preterm as well as term HM feeding. ${ }^{4}$ In practice preterm infants are subjected to HM feeding in varying proportions. Assessment of anti-infective benefits of HM is complicated by the impact of heat treatment, which is known to alter the immunological properties of milk, ${ }^{8}$ the practice of providing donor milk, and the methods of delivery and storage, which may include freezing. ${ }^{9}$ Furthermore, providing preterm infants with an adequate supply of good quality breast milk takes enormous commitment from both mothers and professionals, ${ }^{10}$ especially if fresh raw mother's milk is required. Consequently it is important that the benefits of HM in reducing infections are fully evaluated, especially as infections are a major cause of morbidity and mortality in preterm, very low birth weight (VLBW), and extremely low birth weight (ELBW) infants. ${ }^{11}{ }^{12}$ The purpose of this paper is to review the scientific evidence to determine whether human milk feeding protects against infection in preterm infants $>1500 \mathrm{~g}$ (VLBW) and >1000 g (ELBW) infants. Necrotising enterocolitis was excluded from this review, because the relation with infection is not entirely clear and this outcome has already been the subject of a systematic review. ${ }^{13}$

\section{SELECTION OF STUDIES}

Medline, Embase, Cinahl databases, and the Cochrane controlled trials register were systematically searched for publications from 1970 to 2003, using text words and subject headings $(\mathrm{MeSH})$. References from previous reviews and other relevant studies were also examined. Fourteen studies that listed infection as an outcome of feeding HM (fortified or unfortified) versus artificial formula in preterm, VLBW infants were identified. No language restrictions were applied. Five of these studies were excluded for the following reasons: two studies did not specify birth weights, ${ }^{14}{ }^{15}$ two studies assessed only infants $>1500 \mathrm{~g}^{16}{ }^{17}$ and one study did not include infection as an independent outcome measure. ${ }^{18}$

Nine studies - three randomised controlled trials (RCTs) $)^{19-21}$ and six cohort studies ${ }^{22-27}$ matched the prespecified criteria. The studies could not be limited to only VLBW infants, since six publications ${ }^{19-21} 2627$ included some infants $>1500$ g. Each study was evaluated for definitions of HM feeding, assessment of outcomes, potential confounding factors, and statistical analysis and power. ${ }^{28}$

\section{OVERVIEW OF STUDIES}

Table 1 shows the characteristics of the nine studies. The three RCTs were carried out in India from 1980 to 1984 while the six observational studies were prospective cohort studies from the USA, UK, Australia, and Mexico. A total of 1131 infants-769 infants from cohort studies and 362 from randomised trials-were assessed (fig 1); $86.4 \%$ of infants in the cohort studies were $<1500 \mathrm{~g}$, while $13.8 \%$ were $<1500 \mathrm{~g}$ in the RCTs. All studies concluded that HM feeding had a protective effect in reducing infections in preterm, low birth weight infants.

\section{CLASSIFICATION OF HM FEEDING}

A major flaw noted in all the studies was the lack of a consistent definition of HM fed groups or methods used to quantify HM intake. Despite the current practice in most hospitals of providing any available HM to infants, the imprecise categorisation of feeding - that is, grouping infants with differing degrees of HM intake together, reduces the scientific validity of studies. Further, the true effect of HM may be grossly underestimated because of the varied definitions of HM feeding used in these studies. Exclusive HM feeding (with or without preterm fortifier) was reported in only $86(11.1 \%)$ infants in the cohort studies and 113 infants $(31.2 \%)$ in RCTs. It was not possible to ascertain the number of infants $<1500 \mathrm{~g}$ who were exclusively HM fed in

Abbreviations: ELBW, extremely low birth weight; $H M$, human milk; $\mathrm{RCT}$, randomised controlled trial; UTI, urinary tract infection; VLBW, very low birth weight 


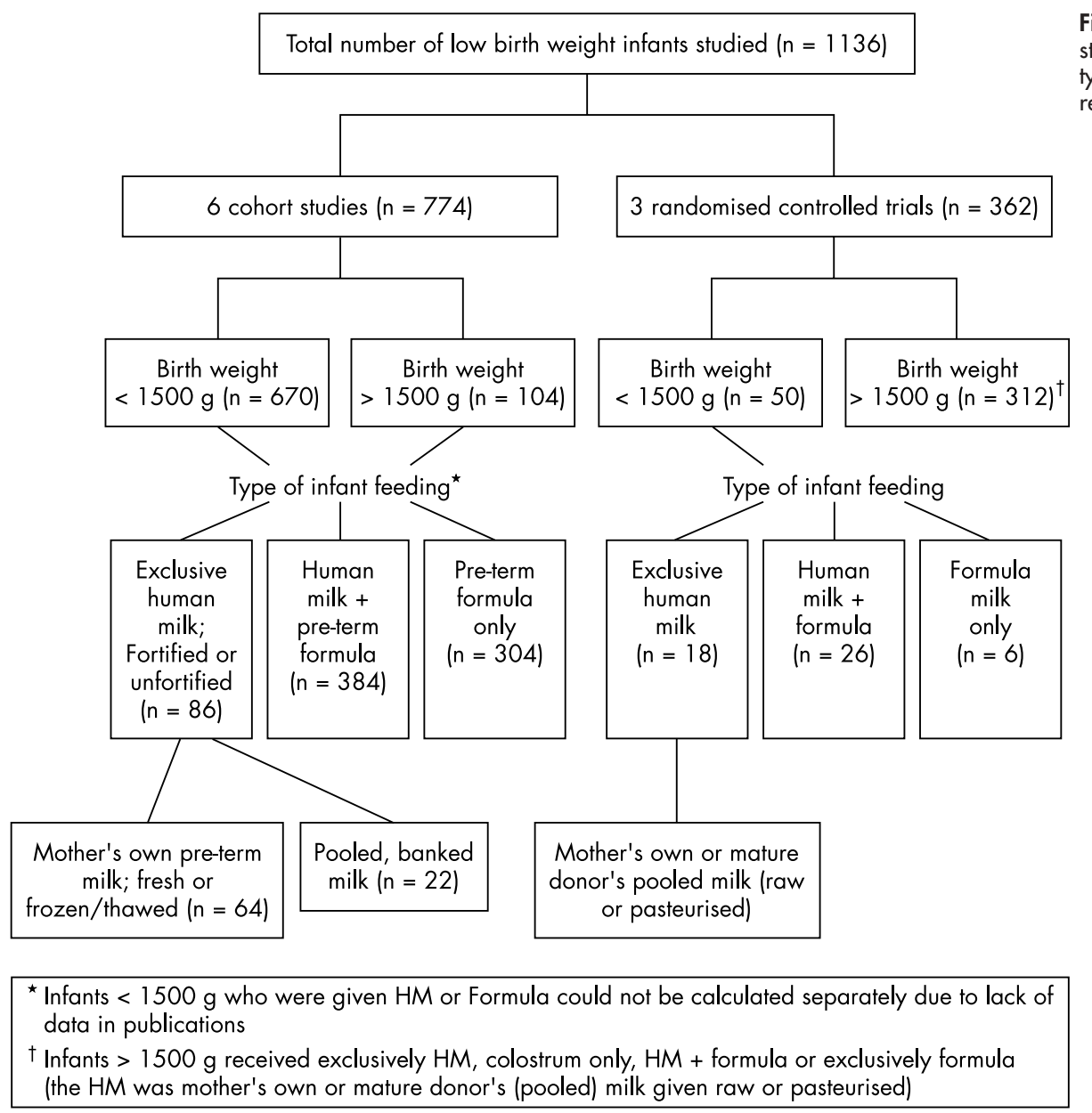

Figure 1 Total number of infants in studies broken down according to study type, birth weight, and type of feed received.

Infants > 1500 g received exclusively $\mathrm{HM}$, colostrum only, $\mathrm{HM}+$ formula or exclusively formula (the HM was mother's own or mature donor's (pooled) milk given raw or pasteurised)

the cohort studies, but only 18 infants were exclusively HM fed in the RCTs (fig 1 ). The remaining "HM fed" infants in all studies received a combination of HM and formula with large variations in the proportions of each (table 1). The type of HM too differed between studies (fig 1), causing further confusion in interpretation of results since the effect of storage and processing on HM are diverse. ${ }^{29}$ In the RCTs too, HM groups varied from infants given only colostrum and formula milk ${ }^{20}$ to others fed unknown amounts of raw or pasteurised, pooled, HM. ${ }^{19}{ }^{21}$ A further problem with definitions is illustrated by a study where the HM fed group were infants who had $40 \%$ of enteral intake as HM. ${ }^{22}$ This definition is flawed because smaller weaker infants receiving primarily intravenous nutrition with minimal enteral intake may be wrongly classified in the higher HM categories. The duration of HM feeding was not mentioned or taken into account in five studies, ${ }^{19-212526}$ and subgroup analysis of different birth weight groups was not reported in any.

\section{OUTCOME MEASURES}

Sepsis was the main outcome measure examined in four cohort studies, while one assessed necrotising enterocolitis, urinary tract infections (UTI), and diarrhoea ${ }^{27}$ (table 1). One long term follow up study examined a range of infections including coryza, otitis media, and bronchiolitis. ${ }^{26}$ Most investigators used uniform criteria such as clinical signs and positive blood cultures to diagnose sepsis. However, interpretation of both laboratory results and clinical signs presents difficulties when diagnosing sepsis in preterm infants, ${ }^{30}$ especially as the severity of illness was not considered in any of the studies. The majority of neonatal sepsis such as bacteraemia and pneumonia is ill defined and consequently very precise diagnostic definitions are required to ensure accuracy of outcome measures in a study. Grouping all infection together as an outcome measure also presents problems since diagnostic criteria and clinical implications are obviously different for infections such as meningitis, urinary infection, and diarrhoea. Furthermore, any protective effect confined to a certain type of infection may be masked. Two cohort studies attempted to diagnose UTI, diarrhoea, or other infections, but the results proved difficult to interpret since one study did not provide any information on how infections were diagnosed or the duration of HM feeding. ${ }^{27}$ The results of the other study, which included 24 HM fed infants, were entirely dependent on subjective parental reporting of duration of upper respiratory symptoms. ${ }^{26}$ If formula fed infants have an increased rate of clinically significant infections, they might be expected to have a longer hospital stay. The duration of hospital stay was assessed in six studies in relation to the type of milk intake, but a significant difference was found in only one of these studies. $^{23}$ The RCTs reported on a range of infections including sepsis, diarrhoea, conjunctivitis, thrush, and pyoderma, but similar problems in confirming infections also applies to these studies.

\section{HM FEEDING AND INFECTION}

An infant is most susceptible to infection during the early neonatal period when enteral intake is minimal or nonexistent. ${ }^{31}$ Therefore averaging HM intake for the entire study period and then comparing infection rates as done by some investigators, ${ }^{23}{ }^{25-27}$ will obscure the true picture, even though 
Table 1 Characteristics and results of studies

\begin{tabular}{|c|c|c|c|c|c|c|}
\hline $\begin{array}{l}\text { First author, location, } \\
\text { and study type }\end{array}$ & n & Study period & $\begin{array}{l}\text { Definition of human } \\
\text { milk (HM) intake }\end{array}$ & $\begin{array}{l}\text { Statistical analysis and } \\
\text { outcome }\end{array}$ & Confounding factors & Major problems* \\
\hline $\begin{array}{l}\text { El Mohandes, } \\
\text { USA, cohort }\end{array}$ & $\begin{array}{l}\text { T } 173+ \\
\text { I } 59 \\
\text { C } 114\end{array}$ & 0-38 days & $\begin{array}{l}\text { HM only as enteral } \\
\text { nutrient } \geqslant 1 \text { week or } \\
\text { as } 40 \% \text { of enteral } \\
\text { calorie intake + FM }\end{array}$ & $\begin{array}{l}\text { Survival analysis using } \\
\text { time to infection: lower } \\
\text { incidence of sepsis in } \\
\mathrm{HM} \text { group; } \mathrm{OR}=0.38 \mp \text {, } \\
\mathrm{Cl}=0.05-0.95 \S \\
\mathrm{p}=0.04\end{array}$ & $\begin{array}{l}\text { None mentioned or } \\
\text { controlled }\end{array}$ & $\begin{array}{l}\text { Flawed definition of HM } \\
\text { feeding } \\
\text { No exclusively HM fed } \\
\text { group } \\
\text { Infection severity not } \\
\text { assessed }\end{array}$ \\
\hline $\begin{array}{l}\text { Schanler, }{ }^{21} \text { USA, } \\
\text { cohort }\end{array}$ & $\begin{array}{l}\text { T } 108 \\
\text { I } 62 \\
\text { C } 46\end{array}$ & 0-9 weeks & $\begin{array}{l}>50 \mathrm{ml} / \mathrm{kg} / \text { day } \mathrm{HM} \\
\text { averaging through } \\
\text { hospital stay }+\mathrm{FM}\end{array}$ & $\begin{array}{l}\text { Logistic regression: } \\
\text { lower proportion of } \\
\text { sepsis episodes in } \\
\mathrm{HM} \text { group; } \mathrm{OR}=0.46 \\
\mathrm{Cl}=0.24-0.87 \\
\mathrm{p}=0.016\end{array}$ & $\begin{array}{l}\text { Controlled: antenatal } \\
\text { steroid exposure } \\
\text { Not controlled: maternal } \\
\text { education, maternal } \\
\text { contact and holding, } \\
\text { milk intakes }\end{array}$ & $\begin{array}{l}\text { No subgroup analysis of } \\
\text { exclusive HM fed group } \\
\text { Severity of infection not } \\
\text { assessed } \\
\text { Important confounders } \\
\text { not controlled }\end{array}$ \\
\hline $\begin{array}{l}\text { Furman, }{ }^{22} \text { USA, } \\
\text { cohort }\end{array}$ & $\begin{array}{l}\text { T } 119 \\
179 \\
\text { C } 40\end{array}$ & $0-6$ weeks & $\begin{array}{l}\text { Graded doses } 1-24, \\
25-49, \geqslant 50 \mathrm{ml} / \mathrm{kg} \\
\mathrm{HM} \text { through } \\
\text { week } 4+\mathrm{FM}\end{array}$ & $\begin{array}{l}\text { Poisson regression } \\
\text { analysis: lower number } \\
\text { of sepsis episodes in } \\
\geqslant 50 \mathrm{ml} / \mathrm{kg} \mathrm{HM} \text { group; } \\
\mathrm{RR}=0.27, \mathrm{Cl}=0.08- \\
0.95, \mathrm{p}<0.05\end{array}$ & $\begin{array}{l}\text { Controlled: birth } \\
\text { weight, gender, } \\
\text { ethnicity } \\
\text { Not controlled: } \\
\text { dexamethasone }\end{array}$ & $\begin{array}{l}\text { No exclusive HM fed } \\
\text { group } \\
\text { Severity of infection not } \\
\text { assessed } \\
\text { Important confounder not } \\
\text { controlled }\end{array}$ \\
\hline $\begin{array}{l}\text { Hylander, }{ }^{23} \text { USA, } \\
\text { cohort }\end{array}$ & $\begin{array}{l}\text { T } 212 \\
\text { I } 123 \\
\text { C } 89\end{array}$ & Hospital stay & $\begin{array}{l}\text { Any amount of } \\
\mathrm{HM}+\mathrm{FM} \\
\text { Duration unknown }\end{array}$ & $\begin{array}{l}\text { Logistic regression on } \\
\text { selected group of } \\
\text { measured variables: } \\
\text { lower odds of infection } \\
\text { in } \mathrm{HM} \text { groups; } \\
\mathrm{OR}=0.46 \\
\mathrm{Cl}=0.24-0.87 \\
\mathrm{p}=0.016\end{array}$ & $\begin{array}{l}\text { Controlled: maternal } \\
\text { sociodemographic } \\
\text { factors, birth weight, } \\
5 \text { minute Apgar, days } \\
\text { of mechanical } \\
\text { ventilation }\end{array}$ & $\begin{array}{l}\text { Flawed definition of HM } \\
\text { feeding } \\
\text { No exclusive HM fed } \\
\text { group } \\
\text { Severity of infection not } \\
\text { assessed, duration of } \\
\text { feeding unknown }\end{array}$ \\
\hline $\begin{array}{l}\text { Blaymore-Bier, }{ }^{25} \\
\text { Australia, cohort }\end{array}$ & $\begin{array}{l}\text { T } 39 \\
\text { I } 24 \\
\text { C } 15\end{array}$ & $\begin{array}{l}1,3,7 \\
12 \text { months }\end{array}$ & $\begin{array}{l}\text { Any amount of } \\
\text { HM+FM up to } \\
1 \text { year }\end{array}$ & $\begin{array}{l}\text { ANCOVA: lesser } \\
\text { days of URTI symptoms } \\
\text { at: } 1 \text { month, } p=0.02 \text {, } \\
\text { and } 7 \text { months, } \\
p=0.006\end{array}$ & $\begin{array}{l}\text { Controlled: } \\
\text { socioeconomic status }\end{array}$ & $\begin{array}{l}\text { Small numbers with only } \\
5 \text { infants exclusively HM } \\
\text { fed } \\
\text { Bias in detecting outcome }\end{array}$ \\
\hline $\begin{array}{l}\text { Contreras-Lemus, }{ }^{24} \\
\text { Mexico, cohort }\end{array}$ & $\begin{array}{l}\text { T } 118 \\
159 \\
\text { C } 59\end{array}$ & Hospital stay & $\begin{array}{l}\text { Preterm HM only } \\
\text { Duration unknown }\end{array}$ & $\begin{array}{l}\chi^{2} \\
\text { Lower incidence of } \\
\text { diarrhoea; } R R=9 \text {, and } \\
\text { urinary infection; RR5 } \\
\text { in HM group, } p<0.01\end{array}$ & $\begin{array}{l}\text { None mentioned or } \\
\text { accounted for }\end{array}$ & $\begin{array}{l}\text { No details of diagnosis of } \\
\text { outcome measures. } \\
\text { Duration of feeding } \\
\text { unknown }\end{array}$ \\
\hline $\begin{array}{l}\text { Narayanan, } \\
\text { India, RCT }\end{array}$ & $\begin{array}{l}\text { T } 70 \\
\text { I } 32 \\
\text { C } 38\end{array}$ & Hospital stay & $\begin{array}{l}\text { EBM (mother's own or } \\
\text { mature donor) + FM } \\
\text { Duration unknown }\end{array}$ & $\begin{array}{l}\chi^{2} \text { test } \\
\text { Lower infection rate } \\
\text { in } H M \text { group }(n=9) \text {, } \\
\text { FM }(n=24), p<0.01\end{array}$ & $\begin{array}{l}\text { None mentioned or } \\
\text { accounted for }\end{array}$ & $\begin{array}{l}\text { Small numbers with only } \\
5 \text { infants }<1500 \mathrm{~g} \\
\text { Flawed definition of HM } \\
\text { feeding, duration } \\
\text { unknown } \\
\text { Lack of exclusive HM fed } \\
\text { group }\end{array}$ \\
\hline $\begin{array}{l}\text { Narayanan, } \\
\text { India, RCT }\end{array}$ & $\begin{array}{l}T 66 \\
133 \\
\text { C } 33\end{array}$ & Hospital stay & $\begin{array}{l}\text { Colostrum } 10 \mathrm{ml} \text { TDS } \\
\text { (mother's own or } \\
\text { mature donor) + FM } \\
\text { Duration unknown }\end{array}$ & $\begin{array}{l}\chi^{2} \text { test } \\
\text { Lower infection rate in } \\
\text { HM group }(n=7), F M \\
(n=18), p<0.01\end{array}$ & $\begin{array}{l}\text { None mentioned or } \\
\text { accounted for }\end{array}$ & $\begin{array}{l}\text { Small numbers with only } \\
5 \text { infants }<1500 \mathrm{~g} \\
\text { Flawed definition of HM } \\
\text { feeding, duration } \\
\text { unknown } \\
\text { Lack of exclusive HM fed } \\
\text { group }\end{array}$ \\
\hline $\begin{array}{l}\text { Narayanan, }{ }^{19} \text { India, } \\
\text { RCT Narayanan }\end{array}$ & $\begin{array}{l}\text { T } 226 \\
\text { I } 169\end{array}$ & Hospital stay & $\begin{array}{l}\text { Raw or pasteurised } \\
\text { EHM (mother's own } \\
\text { or mature donor) } \\
\text { Duration unknown }\end{array}$ & $\begin{array}{l}\chi^{2} \text { test } \\
\text { Greater infection rate } \\
\text { pasteurised HM + FM } \\
\text { group } 33.3 \% \text {, raw HM } \\
\text { group: } 10.5 \%, p<0.05\end{array}$ & $\begin{array}{l}\text { None mentioned or } \\
\text { accounted for }\end{array}$ & $\begin{array}{l}\text { Inadequate numbers with } \\
\text { only } 20 \text { infants }<1500 \mathrm{~g} \\
\text { No exclusively formula } \\
\text { fed group** } \\
\text { Duration of HM feeding } \\
\text { unknown }\end{array}$ \\
\hline
\end{tabular}

*No precalculation of sample size in any study.

$\dagger T$, total number in study; I, number in intervention group; $C$, number in control group.

†OR, odds ratio.

$\S \mathrm{Cl}, 95 \%$ confidence interval.

RR, relative risk.

${ }^{* *}$ All control infants were exclusively fed formula milk (FM), except in Narayanan et al ${ }^{9}$ where the control group was given pasteurised HM + formula milk.

there may be some value in a minimal HM intake during the initial few days. The precise timing of infections in relation to start of enteral feeding (whether infants in formula groups developed infections sooner than HM groups, and the effects on infection rates once HM feeding was discontinued) was not examined in any study. Though a dose-response effect was assessed in two studies, ${ }^{24}{ }^{25}$ only one study showed that the lowest rates of sepsis were in infants consuming $\geqslant 50 \mathrm{ml} /$ $\mathrm{kg} /$ day of $\mathrm{HM}^{, 24}$ while any amount of HM seemed adequate to lower infection rates in the other study..$^{25}$ 


\section{POTENTIAL CONFOUNDING VARIABLES AND STATISTICAL ANALYSIS}

From a statistical perspective, most cohort studies showed bias in favour of HM groups in terms of higher maternal sociodemographic variables (table 1). These included greater avoidance of alcohol, smoking, and illegal drug taking and better antenatal care during the prenatal period. Some HM fed groups also had more maternal visits and contact with mothers, differences in duration of oxygen or steroid therapy, and higher milk intakes. ${ }^{23}$ There are also many other risk factors that may predispose an infant to late onset sepsis including parenteral lipids, male gender, duration of antibiotic use, and $\mathrm{H}_{2}$ antagonists. ${ }^{32-34}$ Four cohort studies ${ }^{23-25} 27$ attempted to account for at least some variables, whereas two studies neglected to adjust for any confounding factors in the analysis ${ }^{22}{ }^{26}$ (table 1). No study attempted any form of matching in order to eliminate the most important confounding variables. However, some of the studies were too small to make this possible. ${ }^{19222627}$ Consequently results must be interpreted cautiously, since adjustment for covariates may change differences in infection rates between HM and formula fed infants.

The authors' conclusions from all nine studies indicate that $\mathrm{HM}$ had a protective effect in reducing infection when compared with formula milk (table 1). HM feeding did not increase infection rates in any study. If the results are taken at face value they are very encouraging. One trial reported $0.3 \pm 0.5$ episodes of sepsis/infant in the HM group and $0.6 \pm 0.7$ episodes/infant in the formula group, while in another, the HM group had 0.09 episodes of sepsis/infant and the formula group had 0.4 episodes/infant during the study period..$^{23}$

\section{CONCLUSIONS}

There are serious methodological flaws in all of the cohort studies which include poor study design, inadequate sample sizes, neglecting to account for some confounders, failure to eliminate the effects associated with maternal choice of feeding method, and other maternal sociodemographic variables (table 1). Definitions of HM feeding and outcome measures were inconsistent and inadequate. All studies reviewed in this paper, including the RCTs, used arbitrary sample sizes without prestudy power calculation. Many reviews have quoted the three RCTs as sound evidence that HM protects preterm, VLBW infants from infection. However, in these three trials, only 50 VLBW infants in total were studied and of these, only 18 exclusively HM milk fed. No ELBW infants were included. Clearly there is a possibility of imbalances between covariates in two groups with small sample sizes, even when the groups are selected using randomisation. Further, these studies were carried out in a developing country with a greatly different infection risk when compared to developed countries, at a time when preterm formulae were not developed and lacked essential nutrients specifically designed for preterm infants. ${ }^{35}$ Therefore, generalisation of these results to include all VLBW infants would not be appropriate. Therefore, benefits of HM feeding in preventing infection in preterm, VLBW infants is not conclusively proven by the currently available evidence.

\section{FUTURE RESEARCH}

As the value of HM feeding in preventing infection in preterm infants remains uncertain, further study is recommended. The greatest barrier to collecting evidence regarding effects of HM on infection is the impossibility of carrying out an RCT for ethical reasons. To calculate sample sizes for a future study we have used data from one $\mathrm{RCT}^{19}$ (table 1). The primary outcome in this trial was infection rates: raw HM group, $\mathrm{n}=6(10.5 \%)$; formula milk + pasteurised HM group, $\mathrm{n}=19(33.5 \%)$. In order to detect this difference in a future study of independent groups with $90 \%$ power and two sided significance of 5\%, 64 are required in each group with an addition for dropout. Since an RCT is not possible, it is likely that imbalances between the groups would be observed. Logistic regression could be used to adjust for any imbalances, but the addition of covariates would inflate the sample size of 128 described above. Alternatively a matched pairs design could be used. In this case, using the same proportions a total of 47 discordant pairs, leading to a sample size of 127 pairs plus an addition for dropout, would be required for $90 \%$ power and two sided significance of $5 \%$.

HM feeding and outcome measures must be adequately defined. We suggest that HM feeding should be defined as total oral feeding, exclusively with mother's own breast milk for the study period. New techniques in breast massage and pumping would make this a viable proposition. ${ }^{36} \mathrm{HM}$ fortifiers must be accepted, as they are often required to ensure adequate growth. ${ }^{37}$ Assessment of infection should begin with the onset of milk feeds and a detailed, precise record of milk intake and duration of HM feeding is essential.

The primary outcome must be a common event. Preterm infants frequently have courses of antibiotics for nonspecific, general, or respiratory deterioration. Using such events would require rigorous evaluation using predefined criteria to determine inclusion as an episode of sepsis. These criteria should take account of illness severity, inflammatory markers, changes in cell counts, culture results, and response to antibiotics. No evaluation is $100 \%$ discriminatory, but would be valid if applied equally to both groups. Clearly, all episodes of clearly defined infection, such as staphylococcal skin infection or meningitis, should also be recorded.

The length of the study should probably equate with the period when infants are at the greatest risk of infection. Neonatal human milk feeding may have long lasting benefits during the first year of life, but as the infections encountered are different, a separate long term follow up protocol would be required, even if the same cohort of patients was used. No benefit would result in undertaking further small studies on this subject; one large study is needed. The emergence of neonatal networks should make this type of study a viable proposition.

\section{Authors' affiliations}

A de Silva, S A Spencer, Neonatology Unit, University Hospital of North Staffordshire, Stoke on Trent, UK

P W Jones, School of Computing and Mathematics, Keele University, Staffordshire, UK

\section{REFERENCES}

1 Molbak K, Jensen $\mathrm{H}$, Ingholt L, et al. Risk factors for diarrheal disease incidence in early childhood: a community cohort study from Guinea-Bissau Am J Epidemiol 1997; 146:273-82.

2 Ashraf RN, Jalil SZ, Karlberg J, et al. Breast feeding and protection against neonatal sepsis in a high risk population. Arch Dis Child 1991;66:488-90.

3 Naficy AB, Abu-Elyazeed R, Holmes JL, et al. Epidemiology of rotavirus diarrhea in Egyptian children and implications for disease control. Am J Epidemiol 1999;150:770-7.

4 Groer M, Walker WA. What is the role of preterm breast milk supplementation in the host defenses of pre term infants? Science vs. fiction. Adv Pediatr 1996;43:335-58.

5 Kelleher SL, Lonnerdal B. Immunological activities associated with milk. Adv Nutr Res 2001;10:39-65.

6 Mathur B, Dwarkadas AM, Sharma VK, et al. Anti-infective factors in preterm human colostrum. Acta Paediatr Scand 1990;79:1039-44.

7 Delneri MT, Carbonare SB, Silva ML, et al. Inhibition of enteropathogenic Escherichia coli adhesion to HEp-2 cells by colostrum and milk from mothers delivering low-birth-weight neonates. Eur J Pediatr 1997; 156:493-8.

8 Schmidt E. Effects of varying degrees of heat treatment on milk protein and its nutritional consequences. Acta Paediatr Scand Suppl 1982;296:41-3.

9 Pardou A, Serruys E, Mascart-Lemone F, et al. Human milk banking: influence of storage processes and of bacterial contamination on some milk constituents. Biol Neonte 1994;65:302-9. 
10 Jones L, Spencer A. Promoting successful breast feeding. Part 2. Pract Midwife 2002;5:22-4

11 Isaacs D, Barfield CP, Grimwood K, et al. Systemic bacterial and fungal infections in infants in Australian neonatal units. Australian Study Group for Neonatal Infections. Med J Aust 1995;162:198-201.

12 Beck Sague CM, Azimi P, Fonseca SN, et al. Bloodstream infections in neonatal intensive care unit patients: results of a multi-centre study. Paediatr Infect Dis J 1994:13:1110-16.

13 McGuire W, Anthony MY. Donor human milk versus formula for preventing necrotising enterocolitis in preterm infants: systematic review. Arch Dis Child Fetal Neonatal Ed 2003;88:F11-14.

14 Narayanan I, Prakash K, Guiral VV. The value of human milk in the prevention of infection in the high-risk low-birth-weight infant. J Pediatr 1981;99:496-8.

15 Narayanan I, Prakash K, Prabhakar AK, et al. A planned prospective evaluation of the anti-infective property of varying quantities of expressed human milk. Acta Paediatr Scand 1982;71:441-5.

16 Guitierezz JL, Fernandez OV. Human colostrums in the prevention of diarrhea and necrotising enterocolitis. Bol Med Hosp Infant Mex 1980;37:23-30.

17 Sur D, Mondal SK, Gupta DN, et al. Impact of breastfeeding on weight gain and incidence of diarrhea among low birth weight infants of an urban slum of Calcutta. Indian Pediatr 2001;38:381-4.

18 Patel RB, Khanna SA, Lahiri K, et al. Breast milk in low birth weight babies. Indian J Pediatr 1981:48:195-6.

19 Narayanan I, Prakash K, Bala S, et al. Partial supplementation with expressed breast-milk for prevention of infection in low-birth-weight infants. Lancet 1980;2:561-3.

20 Narayanan I, Prakash K, Verma RK, et al. Administration of colostrum for the prevention of infection in the low birth weight infant in a developing country. $J$ Trop Pediatr 1983;29:197-200.

21 Narayanan I, Prakash K, Murthy NS, et al. Randomised controlled trial of effect of raw and holder pasteurised human milk and of formula supplements on incidence of neonatal infection. Lancet 1984;2:1111-13.

22 El Mohandes AE, Picard MB, Simmens SJ, et al. Use of human milk in the intensive care nursery decreases the incidence of nosocomial sepsis. J Perinatol 1997:17:130-4.

23 Schanler RJ, Schulman RJ, Lau C. Feeding strategies for premature infants: beneficial outcomes of feeding fortified human milk versus preterm formula. Pediatrics 1999;103:1150-6.
24 Furman L, Taylor $\mathrm{G}$, Minich $\mathrm{N}$, et al. The effect of maternal milk on neonatal morbidity of very low-birth-weight infants. Arch Pediatr Adolesc Med 2003;157:66-71.

25 Hylander MA, Strobino DM, Dhanireddy R. Human milk feedings and infection among very low birth weight infants. Pediatrics 1998;102:E38.

26 Blaymore Bier JA, Oliver T, Ferguson A, et al. Human milk reduces outpatient upper respiratory symptoms in premature infants during their first year of life. $J$ Perinatol 2002;22:354-9.

27 Contreras-Lemus J, Flores Huerta S, Cisneros-Silva I, et al. Morbidity reduction in preterm newborns fed with milk of their own mothers. Bol Med Hosp Infant Mex 1992 Oct, 49:671-7.

28 Bauchner H, Leventhal J, Shapiro, eds. Studies of breast feeding and infections. How good is the evidence? JAMA 1986;256:887-92

29 Lawrence RA. Milk banking: the influence of storage procedures and subsequent processing on immunologic components of human milk. Adv Nutr Res 2001;10:389-404.

30 Dear P. Infection in the newborn. In: Rennie JM, Roberton NRC, eds. Textbook of neonatology, 3rd edn. London: Churchill Livingstone, 1999:1117-20.

31 Stoll BJ, Gordon T, Korones SB, et al. Early onset sepsis in very low birth weight neonates; a report from the National Institute of Child Health and Human Development Neonatal Research Network. J Pediatr 1996 Jul, 129:72-80

32 Fanaroff $A A$, Korones $S B$, Wright $L L$, et al. Incidence, presenting features, risk factors and significance of late onset septicemia in very low birth weight infants. The National Institute of Child Health and Human Development Neonatal Research Network. Pediatr Infect Dis J 1998;17:593-8.

33 Auriti C, Maccallini A, Di Liso G, et al. Risk factors for nosocomial infections in a neonatal intensive care unit. $J$ Hosp Infect 2003;53:25-9.

34 Brodies SB, Sands KE, Gray JE, et al. Occurrence of nosocomial bloodstream infections in six neonatal intensive care units. Pediatr Infect Dis J 2000;19:56-65.

35 Greer FR. Feeding the premature infant in the 20th century. J Nutr 2001;131:426S-30S.

36 Jones E, Dimmock P. Spencer SA. A randomised controlled trial to compare methods of milk expression after pre term delivery. Arch Dis Child Fetal Neonatal Ed 2001;85:F91-5.

37 Polberger NC, Raiha P, Juvonen GE, et al. Individualized protein fortification of human milk for preterm infants: comparison of ultrafiltrated human milk protein and a bovine whey fortifier. $J$ Pediatr Gastroenterol Nutr 1999;29:332-8. 